\title{
RESUME HUKUM TATA NEGARA
}

NUR AMALIA MAGFIRA.A

10200120198

HTN-E

\section{PEMBAHASAN}

\section{A. PENGERTIAN HUKUM TATA NEGARA}

Hukum tata negara adalah sebuah hukum yang mengatur seluruh badan negara baik itu eksekutif,legislatif,dan yudikatif atau Lembaga-lembaga lain yang memiliki kedudukan hukum yang sama yang berlaku pada wilayah tertentu.

Hukum tata negara tidak bisa dilepaskan dengan hubungan ilmu-ilmu yang ada seperti Ilmu Negara,Hukum Adminitasi Negara,Ilmu Politik dan masih banyak ilmu-ilmu lain. Hukum tata negara ini memiliki korelasi dan hubungan yang erat satu sama lain dengan ilmu-ilmu lain sehingga tidak dapat dipisahkan dengan ilmu-ilmu lain.

Lingkup kajiannya pun menyangkut Lembaga negara yang ada di wilayah tertentu serta kewenangan dari Lembaga negara tersebut baik eksekutif,yudikatif,dan legislatif.Hukum tata negara ini juga mengatur bentuk sistem pemerintahan yang sedang diberlakukan di sebuah negara.

Secara umum hukum tata negara memiliki sumber sumber hukum yang digunakan dalam wilayah tetentu atau wilayah yang ada di Indonesia.

Adapun sumber-sumber hukumnya secara umum adalah:

1. Peraturan-peraturan tertulis undang-undang dasar 1945 dan peraturan perundang undangan yang ada di bawahnya secara legastending dalam peraturan yang telah disahkan oleh lembaga yang berwenang yang telah berlaku.

2. Putusan hakim terdahulu (yurisprudensi).

Sumber hukum ini dapat di pakai Ketika kondisi dan situasi terjadi pada waktu sekarang yang sama dengan kondsi dan situasi yang terjadi pada masa lalu.

3. Konvensi ketatanegaraan.

Sumber hukum ini mengambil kebiasaan yang pernah terjadi yang di pakai dalam pelaksanaan negara meskipun peraturan ini tidak di buatkan peraturan tertulis.

4. Hukum internasional.

Adalah sebuah hukum yang di ambil dari sebuah perjanjian antar negara,baik itu perjanjian bilateral dan multirateral.

5. Doktrin

Sumber hukum ini itu menggunakan pandangan dan pengetahuan dari seorang ahli yang memiliki kemampuan kredibel dan memiliki peraturan yang sah.

Hukum tata negara memiliki herarki peraturan perundang undangan yang telah di tetapkan dalam pasal 7 dan 8 undang-undang nomor 12 tahun 2011 sebagaimana telah di ubah dengan undang-undang nomor 15 tahun2o19 yang menerankan bahwa ada tingkatan tingkatan tertinggi sampai terendah yang berlaku di Indonesia.Tingkatantingkatannya sebagi berikut:

1. Undang-undang dasar 1945

2. Ketetapan MPR 

3. Undang-undang atau Perpu
4. Peraturan pemerintah
5. Peraturan presiden
6. Peraturan daerah( provinsi)
7. Peraturan daerah( kabupaten /kota)
8. Peraturan-peraturan lain yang ditetapkan oleh Lembaga yang berwenang

Dalam hukum tata negara juga berlaku asas- asas sebagai sebuah pandangan hukum ataupun norma-norma hukum sebagai pengarah dan petunjuk dalam hukum tata negara.Asas asas hukum memiliki fungsi sebagai berikut:

1. Adanya konsistensi

Dalam pelaksanaan hukum tata negara Konsistensi dibutuhkan agar pembentukan dan pelaksanaan Lembaga negara tetap pada konstitusi yang berlaku dalam pelaksanaan kehidupan bermasyarakat,berbangsa dan bernegara sehingga dapat meminimalisir penyimpangan yang terjadi.

2. Mencegah konflik

Asas asas hukum tata negara digunakan untuk mencegah terjadinya konflik antar peraturan-peraturan hukum atau badan badan hukum yang sah sehingga pelaksanaan Lembaga negara dalam menjalankan tugas ,fungsi dan wewenangnya dapat berjalan baik sehingga dapat terjaganya sebuah negara yang ideal.

Adapun asas asas yang di gunakan di Indonesia dan memiliki kekuatan hukum yang tetap adalah:

\section{Asas Pancasila}

Pancasila sebagai pedoman dan pandangan hidup yang digunakan di Indonesia itu menjadikan Lembaga lembag negara memiliki fungsi dan tugas yang jelas dalam pelaksanaan kehidupan bermasyarakat , berbangsa dan bernegara.Pancasila sebagai ideologi yang tidak bisa dilupakan dalam pelaksanaan kehidupan berbangsa dan bernegara karena seluruh perarturan peraturan yang dibuat itu didasari oleh Pancasila baik peraturan tertinggi maupun terendah.

2. Asas negara hukum

Asas negara hukum menjelaskan bahwa kita berada pada sebuah wilayah yang memaksa dan mengikat seluruh masyarakat tanpa terkecuali untuk tunduk dan patuh terhadap hukum.jelas pula bahwa negara Indonesia itu adalah negara hukum sebagaimana telah diamanatkan dalam pasal 1 ayat 3 undang undang dasar 1945 sebagai aturan tertinggi dalam hirarki peraturan prundang undangan yang telah di tetapkan.

3. Asas negara kesatuan

Asas negara kesatuan itu menerankan bahwa adanya penggabungan wilayah wilayah dari sabang sampai Merauke yang kemudian Bersatu menjadi sebuah negara yang dikenal dengan nama indonesia.Asas negara kesatuan itu juga menjelaskan bahwa hanya ada satu pemerintah yang berwenang dalam sebuah negara. Telah jelas pula dalam pasal 1 ayat 1 undang undang dasar 1945 yang menerankan bahwa negara Indonesia adalah nrgara kesatuan yang berbentuk republik.

4. Asas kedaulatan rakyat dan demokrasi 
Asas ini menerankan bahwa kedaulatan tertinggi pada sebuah negara itu berada ada rakyat dan sesuai dengan apa yang dibutuhkan rakyat.sistem demokrasi pun itu harus selalu dilakukan dalam pengambilan keputusan atau pemilihan orang dalam sistem pemerintahan. Ini telah diterankan pada pasal 1 ayat 2 undang undang dasar 1945 yang menjelaskan bahwa kedaulatan ada di tangan rakyat dan dilaksanakan berdasarkan undang undang dasar.

5. Asas pemisahan kekuasaan

Pemisahan kekuasaan yang terjadi sekarang itu terbagi menjadi 3 lembaga yaitu legislatif,eksekutif,dan yudikatif.Kenapa pembagian kekuasaan ini dilakukan yaitu untuk mencegah overdosis kewenangan sehingga sebuah Lembaga memiliki check and belens dan pelaksanaan tugas dan fungsinya dapat tercapai dengan baik.

\section{A. SEJARAH KETATANEGARAAN INDONESIA}

Konstitusi indonesia lahir dari banyaknya rangkain sejarah sehingga membentuk yang namanya konstitusi.Konstitusi ini adalah sebuah hukum yang menjadi landasan penyelenggaraan sebuah negara.konstitusi di indonesia sendiri terbagi menjadi 2,yaitu:

1. Hukum tertulis

Hukum tertulis ini menyangkut peraturan perundang-undangan (undang-undang dasar 1945, Tap MPR,Uud/ Perpu,perturan presiden

2. Hukum tidak tertulis

Hukum tidak tertulis adalah rangkaian peraturan yang diambil dari kebiasaan masyarakat yang menyesuaikan dengan keadaan pada wilayah tertentu. Kebiasaan lah yang menjadi landasan serta pola kehidupan dalam kegiatan sehari hari. Hukum ini tidak dituliskan langsung dapat peraturan perundang undangan tetapi tetap berpadu pada konstitusi dan tidak boleh bertentangan satu sama lain.

Konstitusi yang dianut diindonesia sendiri sudah sering mengalami perubahan .Tercatat dalam sejarah kita sudah mengubah sampai sebanyak 4 kali konstitusi yang kita anut .

1. UUD 1945

Dasar konstitusi pertama kita adalah UUD 1945 yang dipersiapkan oleh sebuah badan yang di sebut BPUPKI ( badan penyelenggara urusan persiapan kemerdekaan Indonesia)

Yang diberikan tugas kbsusu untuk mengurusi segala urusan dalam persiapan kemerdekaan Indonesia baik dari dasar konstitusi sampai kepada hal hal lainnya .

2. Konstitusi RIS

Penerapan sistem konstitusi RIS ini tidak lepas dari pengaruh negara Belanda yang mencoba memecah negara Indonesia . Faktor lain penyebab nya adalah kekalahan negara Jepang dalam peperangan . Dalam konferensi meja bundar telah disepakati bahwa konstitusi RIS berlaku mengantikan UUD 1945 Namun konstitusi RIS ini hanya bersifat sementara pada masa itu. 
3. UUD sementara

Perubahan ketiga terjadi ketika pemerintahan RIS sepakat dengan pemerintahan negara Indonesia untuk mengubah sistem RIS menjadi UUD dasar sementara karena dinilai tidak sesuai dengan keinginan bangsa Indonesia dan semangat proklamator pada tanggal 17 Agustus 1945. Sehingga diperlukan perubahan dari bentuk konstitusi RIS menjadi UUD sementara

4. UUD 1945

Diubahnya kembali UUD sementar menjadi UUD 1945 tidak terlepas dari pengaruh BPUPKI dan PPKI dalam menyusun persiapan kemerdekaan. UUD 1945 inilah yang kemudian dipake hingga saat ini. Dalam penerapan nya kembali UUD 1945 ini telah mengalami amandemen atau perubahan isi sebanyak 4 kali dimulai tahun 1999, 2000,2001 sampai 2002. Perubahan terjadi menyusul adanya kepentingan negara dalam menjalankan sistem pemerintahan . Setidaknya ada banyak pasal dan ketentuan yang diubah dalam amandemen UUD 1945.

Selain konstitusi yang mengalami perubahan dari waktu ke waktu. Sistem pemerintahan , bentuk negara juga mengalami banyak perubahan

A. Bentuk negara

Diindonesia pada saat pembahasan soal bentuk negara mengalami perdebatan yang cukup panjang . Ada perbedaan pendapat tentang bentuk negara yang cocok untuk dianut oleh negara Indonesia.

1. Bentuk negara kesatuan

Banyak yang menyatakan bahwa sistem negara kesatuan sangat cocok diterapkan diindonesia karena kita terdiri atas pulau pulau yang membuat kita harus bersatu . Karena sistem inilah yang dapat memajukan negara Indonesia. Ciri ciri dari negara kesatuan itu adalah

a. Hanya terdapat satu pemerintahan yang berdaulat

b. Sistem yang dianut adalah desentralisasi dan sentralisasi

c. Adanya pembagian tingkatan pemerintah pusat dan daerah

2. Negara federal.

Sistem negara federal dimana terdiri atas berbagai negara bagian yang kemudian memiliki konstitusi dan dasar negara tersendiri sehingga tempat atau lokasi itu memiliki peraturan yang berbeda.

B. Sistem pemerintahan

Telah jelas dalam UUD 1945 sebagai konstitusi tertinggi kita yang menjelaskan bahwa pasal 1 ayat 1 UUD 1945 " Indonesia adalah negara kesatuan yang berbentuk republik". Berarti segala urusan dinegara Indonesia itu menggunakan sistem 
demokrasi . Contoh dalam pemilihan kepala negara itu menggunakan sistem demokrasi bukan berasal dari keturunan .

1. Konstitusi negara Indonesia

Konstitusi adalah aturan aturan yang telah ditetapkan dalam sebuah negara yang secara hukum memiliki dasar hukum yang tetap. Memahami lebih dalam persoalan konstitusi itu tidak lepas dari sifat sifat negara konstitusi itu sendiri . Adapun beberap sifat konstitusi adalah :
1. Fleksibel
2. Tertulis
3. Tidak tertulis
4. Rigid/ kaku

Selain dari sifat yang dimiliki konstitusi. Konstitusi juga memiliki fungsi dan tujuan yang jelas dalam penerapan nya dalam sebuah negara

\section{Fungsi}

Konstitusi adalah landasan sebuah hukum bagian dalam penerapan dan dalam pemisahan sebuah kekuasaan negara, konstitusi juga yang memberikan sebuah kewenangan terhadap lembaga lembaga negara sehingga hubunga. Antar lembaga negara dapat terjalin dengan baik sehingga pelaksanaan dari tugas tugasnya bisa berjalan baik.

Tujuan konstitusi

Memastikan adanya sebuah penyelenggaraan negara yang berdaulat berdasarkan peraturan perundang undangan yang telah ditetapkan dan berlaku pada sebuah negara. Konstitusi diperlukan untuk mengontrol dalam pengawasan penerapan kekuasaan 3 lembaga yaitu eksekutif, legislatif dan yudikatif. Pembagian kekuasaan ini yang mengangkut badan eksekutif, yudikatif dan legislatif ini memiliki tugas untuk bagaimana sistem dalam peraturan itu kemudian sesuai dengan tujuan negara kita

Dalam hukum tata negara yang berlaku di Indonesia itu membagi kekuasaan menjadi 3 lembaga:

\section{A. Legislative}

Legislatif adalah lembaga negara yang menyangkut Dewan Perwakilan Rakyat,Dewan Perwakilan Daerah,dan Majelis Permusyarawatan Rakyat yang memiliki tugas untuk Menyusun dan membuat sebuah peraturan perundang -udangan yang berlaku dan memiliki kekuatan hukum yang sah. 


\section{B.Eksekutif}

Eksekutif adalah lembaga negara yang menyangkut persoalan bagaimana menjalankan pemerintahan negara dalam lingkup presiden dan struktural yang ada di bawahnya.Lembaga eksekutif ini mempunyai tugas dan fungsi menjalankan peraturan perundang-undangan yang telah disusun dalam sebuah peraturan yang telah dibuat oleh badan legislatif.

C. Yudikatif

Yudikatif adalah Lembaga negara yang menyangkut Mahkamah Kostitusi,Mahkamah Agung,dan Komisi Yudisial yang mempunyai tugas dan fungsi mengawasi kinerja dari badan eksekutif.Sebagaimana telah dibuatkan dalam lembaga legislatif. 